\title{
Penentuan Zona Caprock di Sekitar Gunung Talang Menggunakan Metode Resistivitas Konfigurasi Wenner
}

\author{
Syafitri", Ardian Putra \\ Laboratorium Fisika Bumi, Jurusan Fisika \\ Fakultas Matematika dan Ilmu Pengetahuan Alam \\ Kampus UNAND Limau Manis, Padang, 25163, Indonesia \\ *fitrizikrillah3@email.com
}

\begin{abstract}
ABSTRAK
Penentuan zona caprock di daerah Solok telah dilakukan menggunakan metode resistivitas konfigurasi Wenner. Pengukuran dilakukan di 3 titik yang berada di daerah Cupak, Bukit Gadang dan Bukit Sundi. Terdapat tiga lintasan pengukuran dengan panjang lintasan $1050 \mathrm{~m}$. Pengolahan data dilakukan menggunakan software IPI2WIN untuk mendapatkan pemodelan 1D resistivitas batuan terhadap kedalaman. Hasil pengolahan data menunjukkan pada lintasan 1 terdapat 3 lapisan batuan. Lapisan konduktif ditandai dengan nilai resistivitas <20 $\Omega$ m yang terdapat pada kedalaman di bawah $109 \mathrm{~m}$. Lapisan ini diinterpretasikan sebagai batuan lempung dan berfungsi sebagai caprock (batuan penudung) Gunung Talang. Lintasan 2 menunjukkan adanya 4 lapisan batuan, dengan tidak ditemukan keberadaan zona caprock, tapi pada hasil pemodelan terdapat penurunan nilai resistivitas mulai dari kedalaman 78,7 m. Pada lintasan 3 menunjukkan 4 lapisan batuan dan pada lintasan ini juga tidak teridentifikasi zona caprock panas bumi.

Kata kunci: caprock, gunung talang, konfigurasi wenner, metode resistivitas
\end{abstract}

\section{ABSTRACT}

Caprock zone in Solok Regency has been determined using Wenner Array of resistivity method. The acquisition data is conducted in the area of Cupak, Bukit Gadang and Bukit Sundi. There are 3 trajectory paths with a track length of $1050 \mathrm{~m}$. The data is processed by using IPI2WIN software that generates a $1 D$ resistivity-crosssection to the depth of the rock layer. Based on the resistivity cross-section, path 1 has 3 layers of rock. The conductive layer is characterized by a low resistance value of $<20 \Omega m$ located at depth below $109 \mathrm{~m}$. This layer is interpreted as clay rock and serves as a caprock (mountain scarf) gutters. Path 2 shows 4 layers of rock, indicates no presence of caprock zone, but the result of $1 D$ modeling there is a decrease of resistivity value starting from depth $78.7 \mathrm{~m}$. Path 3 also has 4 layers, and there is also no indication of the existence of the geothermal caprock zone.

Keywords: caprock, gunung talang, resistivity method, wenner array

\section{PENDAHULUAN}

Sumatera Barat merupakan provinsi yang memiliki potensi panas bumi, salah satunya terdapat di sekitar Gunung Talang, Kabupaten Solok. Daerah Gunung Talang berada pada jalur sesar aktif yang membelah pulau Sumatera mulai dari Teluk Semangko hingga ke Banda Aceh yang memungkinkan adanya aktivitas vulkanisme di daerah tersebut. Munandar dkk. (2003) menyatakan daerah Gunung Talang yang berada di jalur ring of fire memilik potensi panas bumi yang didukung dengan adanya manifestasi berupa mata air panas, letusan freatik, lapangan fumarol/ solfatara, batuan ubahan hidrotermal dan sinter karbonat. Panas bumi adalah sumber energi panas di dalam air panas, uap air dan batuan bersama mineral dan gas lainnya yang secara alami semuanya tidak dapat dipisahkan dalam suatu sistem panas bumi. Sebuah sistem panas bumi pada dasarnya terdiri dari sistem tata air sebagai fluida, batuan akuifer yang berfungsi sebagai reservoir air, magma sebagai sumber panas, caprock (batuan penudung) sebagai pengunci gerakan dari fluida, dan fracture atau patahan pada batuan sebagai jalur migrasi fluida. Kelima hal ini merupakan satu kesatuan dalam sebuah sistem panas bumi (Dickson dan Fanelli, 2003).

Caprock merupakan lapisan batuan yang memiliki porositas dan permeabilitas yang rendah. Lapisan batuan ini berfungsi sebagai penutup reservoir untuk mencegah keluar atau bocornya fluida panas bumi. Caprock umumnya tersusun oleh lapisan batuan yang terdiri dari mineral lempung sekunder hasil ubahan akibat interaksi fluida dengan batuan yang dilewatinya. Pada lingkungan tektonik aktif, lapisan batuan ini mengalamai deformasi dan membentuk rekahan. Tetapi, dengan adanya proses kimia berupa pengendapan mineral sangat membantu 
dalam menutup rekahan yang terbentuk, seperti pengendapan kalsit dan silika (Haerudin dkk, 2009).

Penentuan zona caprock panas bumi dapat dilakukan melalui survei pendahuluan menggunakan metode geofisika. Metode ini merupakan aplikasi dari ilmu fisika yang digunakan untuk mengidentifikasi objek tertentu di bawah permukaan bumi. Metode ini memanfaatkan adanya kontras sifat fisika dari objek yang dicari, lalu dibandingkan dengan kondisi lingkungan sekitarnya (Milsom, 2003). Metode geofisika yang digunakan untuk kegiatan eksplorasi panas bumi ada beberapa macam, diantaranya metode resistivitas, gravity, geomagnet dan MT (magnetotellurik).

Penelitian yang dilakukan di daerah Bukit Kili - Gunung Talang menggunakan metode MT oleh Kholid dan Marpaung (2011), menghasilkan nilai resistivitas <20 $\Omega$ m yang diidentifikasi sebagai caprock dan diperkirakan tersebar di sekitar mata air panas Batu Berjanjang, mulai dari kedalaman $500 \mathrm{~m}$. Reservoir panas bumi diperkirakan berada di bawah batuan ini dengan ditandai oleh nilai resistivitas 20-100 $\Omega \mathrm{m}$ dengan kedalaman sekitar $1500 \mathrm{~m}$ di bawah permukaan bumi.

Metode geofisika lain yang dapat digunakan untuk penentuan caprock panas bumi adalah metode resistivitas. Menurut Minarto (2007) metode resistivitas sangat bagus digunakan untuk mengetahui kondisi atau struktur geologi bawah permukaan berdasarkan variasi tahanan jenis batuannya. Penelitian yang dilakukannya di daerah panas bumi Mataloko didapatkan lapisan konduktif dengan nilai resistivitas <5 $\Omega \mathrm{m}$ pada kedalaman $800-1000 \mathrm{~m}$ yang diindikasikan sebagai lapisan caprock. Selain itu, Arif dkk (2015) menyatakan metode ini bagus digunakan pada daerah dengan kontras tahanan jenis yang cukup jelas terhadap sekitarnya seperti untuk keperluan eksplorasi panas bumi.

Berdasarkan penelitian sebelumnya di daerah Bukit Kili - Gunung Talang, lapisan caprock ditemukan di sekitar daerah Batu Berjanjang dan tidak dijelaskan luas lapisan tersebut. Untuk melihat penyebarannya, perlu dilakukan survei lebih lanjut di daerah sekitar Gunung Talang, yaitu di daerah Bukit Gadang, Cupak dan Bukit Sundi. Daerah tersebut memiliki manifestasi panas bumi berupa mata air panas, sehingga memungkinkan adanya potensi panas bumi di daerah tersebut. Metode yang digunakan adalah metode resistivitas. Konfigurasi yang digunakan adalah konfigurasi Wenner. Konfigurasi ini dapat digunakan untuk pemetaan bawah permukaan dalam arah lateral. Hal ini dapat dilakukan dengan cara memindahkan titik pengukuran dan mempertahankan jarak antar elektroda arus dan tegangan. Kelebihan konfigurasi ini adalah ketelitian pembacaan tegangan pada elektroda MN lebih baik dengan angka yang relatif besar karena elektroda $\mathrm{MN}$ yang relatif dekat dengan elektroda $\mathrm{AB}$, sehingga lebih sensitif dalam menentukan homogenitas batuan. Selain itu, metode ini memiliki bidang eqipotensial berbentuk bola, sehingga memudahkan dalam perhitungan (Arnata dkk, 2012).

\section{METODE}

Lokasi penelitian berada di daerah panas bumi Bukit Kili - Gunung Talang berlokasi sekitar 9 km dari Kota Arosuka ibukota Kabupaten Solok, dan sekitar $40 \mathrm{~km}$ sebelah Timur

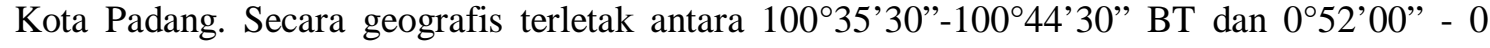
`59'05” LS.

\subsection{Metode Akuisisi Data}

Metode resistivitas adalah metode yang mempelajari sifat aliran listrik di dalam bumi dan bagaimana mendeteksinya di permukaan bumi. Hal ini meliputi pengukuran potensial, arus dan medan elektromagnetik yang terjadi baik secara alami maupun akibat injeksi arus ke dalam bumi (Hendrajaya dan Arif, 1990). Konsep dasar metode ini berdasarakan Hukum Ohm yang ditunjukkan oleh persamaan 1 berikut:

$$
R=\frac{V}{I}
$$

dengan $R$ adalah resistansi bahan $(\Omega), I$ adalah besar kuat arus (ampere), dan $V$ adalah besar tegangan (volt). 
Prinsip dasar dari metode ini adalah kemampuan dari suatu mineral dialiri oleh arus listrik. Mineral yang mudah dialiri oleh arus listrik memiliki resistivitas yang rendah, kebalikannya mineral yang sulit dialiri oleh listrik berarti memiliki resistivitas yang tinggi (Reynolds, 1997).Tiap-tiap medium (lapisan batuan) mempunyai sifat kelistrikan berbeda beda, tergantung dari kandungan logam/non logam, komposisi mineral, kandungan air, permeabilitas, tekstur, suhu dan umur geologi. Ada beberapa konfigurasi elektroda yang sering digunakan, yaitu metode Wenner, Pole- pole, Pole-dipole, Dipole-dipole, Schlumberger dan Wenner-Schlumberger (Reynolds, 1997). Berikut merupakan bentuk konfigurasi Wenner yang ditunjukkan oleh Gambar 1.

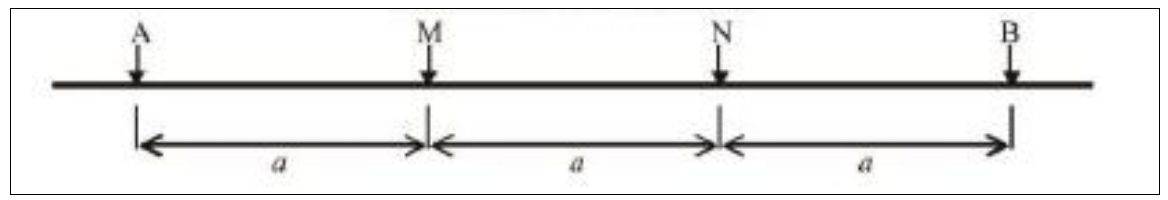

Gambar 1 Konfigurasi Wenner

(Sumber : Telford, 1990)

Untuk faktor geometrinya dapat dirumuskan :

$$
k=2 \pi\left(\frac{1}{A M}-\frac{1}{M B}-\frac{1}{A N}+\frac{1}{N B}\right)^{-1}
$$

dengan $A$ dan $B$ adalah elektroda-elektroda arus, $M$ dan $N$ adalah elektroda-elektroda potensial, $a$ adalah spasi elektroda. Karena jarak antar elektroda sama, maka nilai faktor geometri pada persamaan 2 dapat diganti dengan persamaan berikut :

$$
k=2 \pi a
$$

Peralatan yang digunakan pada saat akuisisi adalah alat resistivitymeter, 4 gulungan kabel, palu, 2 pasang elektroda, 2 aki kering, multimeter, meteran dan GPS. Lokasi pengambilan data berada di daerah Cupak, Bukit Gadang dan Bukit Sundi, Kab. Solok dengan jumlah lintasan 3 buah (Gambar 2). Panjang masing - masing lintasan yaitu $1050 \mathrm{~m}$ dengan 35 titik datum per lintasan.

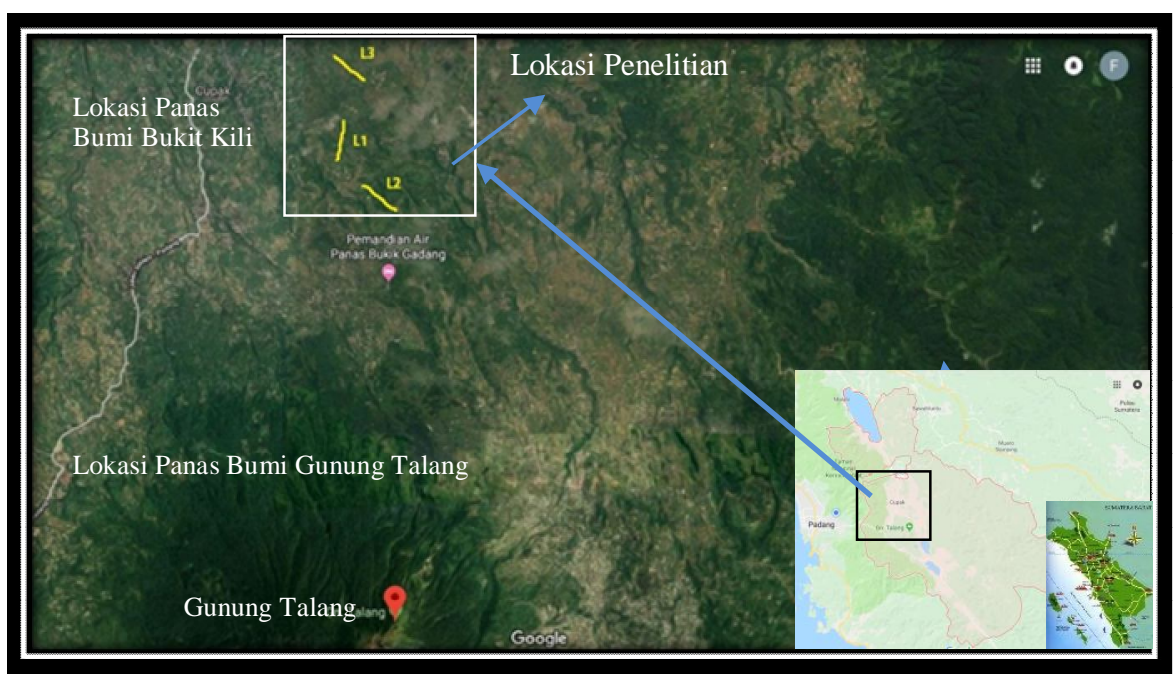

Gambar 2 Lokasi Akuisisi Data

L1 menunjukkan lintasan pengukuran daerah Cupak, L2 menunjukkan daerah Bukit Gadang dan L3 menunjukkan daerah Bukit Sundi. Proses akuisisi data dilakukan dengan mencatat nilai arus dan tegangan $\left(I_{F}, V_{F}, I_{R}, V_{R}\right)$ untuk setiap jarak elektroda pada resistivitymeter mulai titik datum yang pertama sampai yang terakhir. Selain itu, pada saat pengambilan data, koordinat titik pengukuran dicatat menggunakan GPS. Berdasarkan peta geologi, urutan stratigrafi daerah Gunung Talang terdiri dari delapan satuan batuan, yaitu : batuan malihan/metamorf, vulkanik tua, produk Bukit Kili, produk Bukit Bakar, produk vulkanik 
Danau Talang, produk vulkanik Batino, produk vulkanik Jantan, dan endapan permukaan. Berdasarkan peta tersebut, lokasi L1 terletak pada stratigrafi batuan vulkanik Gunung Batino. L2 terletak pada stratigrafi batuan vulkanik Gunung Jantan dan L3 terletak pada stratigrafi batuan endapan permukaan.

\subsection{Pengolahan Data}

Data yang didapatkan dari pengukuran Konfigurasi Wenner diolah dengan Microsoft Excel hingga didapatkan nilai resistivitas semunya. Setelah itu, data diplot menggunakan software IPI2WIN dengan memasukkan besar nilai resistivitas dan jarak elektroda $(A B / 3)$. Hasilnya adalah grafik jarak elektroda $(\mathrm{AB} / 3)$ terhadap resitivitas yang berisikan :

1. Plot jarak elektroda terhadap resistivitas (data hasil pengukuran)

2. Grafik parameter model (nilai ketebalan dan resistivitas tiap lapisan)

3. Grafik jarak elektroda terhadap resistivitas (hasil perhitungan dengan model yang dimasukkan)

Hasil akhir dari pengolahan data menggunakan software ini berupa grafik resistivitas terhadap jarak elektroda. Informasi yang diperoleh adalah \%error, resistivitas tiap lapisan, ketebalan dan kedalaman. Setelah didapatkan grafik, tiga lintasan daerah penelitian tersebut dibuat pemetaan 1 dimensi menggunakan software yang sama.

\subsection{Analisis Data}

Pemisahan lapisan-lapisan batuan dilakukan sesuai dengan nilai resistivitasnya, dilanjutkan dengan mengkorelasikan data resistivitas dari pengolahan yang didapatkan dengan literatur. Interpretasi yang dilakukan harus didukung oleh data geologi daerah penelitian. Selain itu, interpretasi dilakukan dengan asumsi: (1) di bawah permukaan terdapat sejumlah lapisan batuan dengan ketebalan terbatas, dan (2) setiap lapisan batuan mempunyai sifat homogen dan secara kelistrikan bersifat isotropik (diukur dari berbagai arah akan memberikan harga yang sama).

\section{HASIL DAN DISKUSI}

Berdasarkan hasil pengolahan dan interpretasi data 1D menggunakan software IPI2WIN didapatkan grafik hasil plot jarak elektroda dengan resistivitas semu batuan. Grafik tersebut memberikan informasi tentang jumlah lapisan batuan, nilai resistivitas, ketebalan dan kedalaman lapisan batuan. Pendugaan lapisan batuan untuk L1 dapat dilihat pada Tabel 1

Tabel 1 Hasil pengolahan dan interpretasi data L1

\begin{tabular}{ccccc}
\hline Lapisan & $\begin{array}{c}\text { Resistivitas } \\
(\mathbf{\Omega} \mathbf{)}\end{array}$ & $\begin{array}{c}\text { Ketebalan } \\
(\mathbf{m})\end{array}$ & $\begin{array}{c}\text { Kedalaman } \\
(\mathbf{m})\end{array}$ & Jenis Lapisan Batuan \\
\hline I & 50,3 & 0,8 & $0,0-0,8$ & Lapisan tanah penutup \\
II & 5027 & 109 & $0,8-109$ & Lapisan batuan vulkanik \\
III & 17,1 & - & $109-$ & Lapisan batuan lempung \\
\hline
\end{tabular}

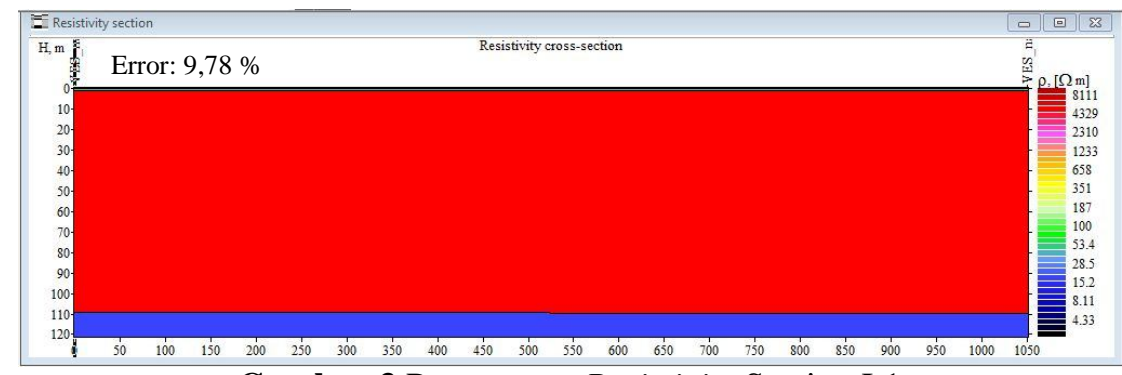

Gambar 3 Penampang Resistivity Section L1

Gambar 3 menunjukkan hasil penampang 1 dimensi menggunakan software IPI2WIN yang menunjukkan nilai resistivitas dan kedalaman bawah permukaan bumi. Penampang tersebut terdiri dari beberapa warna yang berbeda. Perbedaan warna ini menunjukkan variasi nilai resistivitas dari batuan dan jenis material di bawah permukaan bumi. 
Tabel 1 menunjukkan hasil pengolahan dan interpretasi data L1 yang berada di daerah Cupak. Berdasarkan stratigrafi daerah Gunung Talang, daerah Cupak terdiri atas batuan piroklastik dan bongkah lava. Pada tabel tersebut terdapat 3 lapisan batuan dengan nilai resistivitas berbeda. Penentuan jenis lapisan batuan ini berdasarkan nilai resistivitas batuan yang dikemukakan oleh Telford dkk, (1990). Lapisan I dengan nilai resistivitas 50,3 $\Omega \mathrm{m}$ diinterpretasikan sebagai lapisan tanah penutup (top soil) dengan ketebalan 0,8 m. Lapisan tanah penutup tidak diberi batasan nilai resistivitas dan selalu terletak di bagian atas dekat permukaan tanah pada setiap titik sounding (Maruly, 2016). Lapisan II mempunyai nilai resistivitas $5027 \Omega \mathrm{m}$ diinterpretasikan sebagai lapisan batuan vulkanik dengan ketebalan $109 \mathrm{~m}$. Batuan vulkanik ini berupa batuan piroklastik dan lava andesitik. Berdasarkan nilai resistivitasnya, lapisan ini termasuk kedalam jenis lapisan tuff. Lapisan III mengalami penurunan nilai resistivitas $17,1 \Omega \mathrm{m}$ yang diinterpretasikan sebagai lapisan batu lempung dengan ketebalan yang tidak ditentukan dan berada pada kedalaman $109 \mathrm{~m}$ di bawah permukaan bumi.

Batuan lempung merupakan batuan ubahan akibat adanya proses pelapukan batuan silika dengan asam karbonat dan sebagian lagi prosesnya berasal dari panas bumi (Noor, 2012). Batuan ini memiliki porositas dan permeabilitas rendah, sehingga sulit untuk meloloskan fluida ke permukaan. Resistivitas rendah menggambarkan temperatur tinggi dari suatu reservoir panas bumi yang berhubungan dengan batuan konduktif akibat adanya alterasi hidrotermal (Simsek dan Demir, 1991). Berdasarkan nilai resistivitasnya lapisan ini diindikasikan sebagai caprock panas bumi.

Kholid dan Marpaung (2011) menemukan caprock panas bumi disekitar mata air panas Batu Berjenjang dengan nilai resistivitas $<20 \Omega$ m pada kedalaman $500 \mathrm{~m}$. Pada daerah Cupak ini caprock berada pada kedalaman $109 \mathrm{~m}$. Berdasarkan topografi daerah Gunung Talang, daerah Batu Berjanjang merupakan daerah yang relatif landai dan berada di lereng Gunung Talang, sedangkan daerah Cupak terletak pada dataran rendah. Hal ini memungkinkan terdapatnya perbedaan lokasi caprock panas bumi.

Tabel 2 Hasil pengolahan dan interpretasi data untuk L2

\begin{tabular}{ccccc}
\hline Lapisan & $\begin{array}{c}\text { Resistivitas } \\
(\mathbf{\Omega m})\end{array}$ & $\begin{array}{c}\text { Ketebalan } \\
(\mathbf{m})\end{array}$ & $\begin{array}{c}\text { Kedalaman } \\
(\mathbf{m})\end{array}$ & Jenis Lapisan Batuan \\
\hline I & 48,8 & 0,9 & $0,0-0,9$ & Lapisan tanah penutup \\
II & 1931 & 13,8 & $0,9-14,7$ & Lapisan batuan vulkanik \\
III & 4596 & 64 & $14,7-78,7$ & Lapisan batuan vulkanik \\
IV & 86,1 & - & $78,7-$ & Lapisan batuan lempung \\
\hline
\end{tabular}

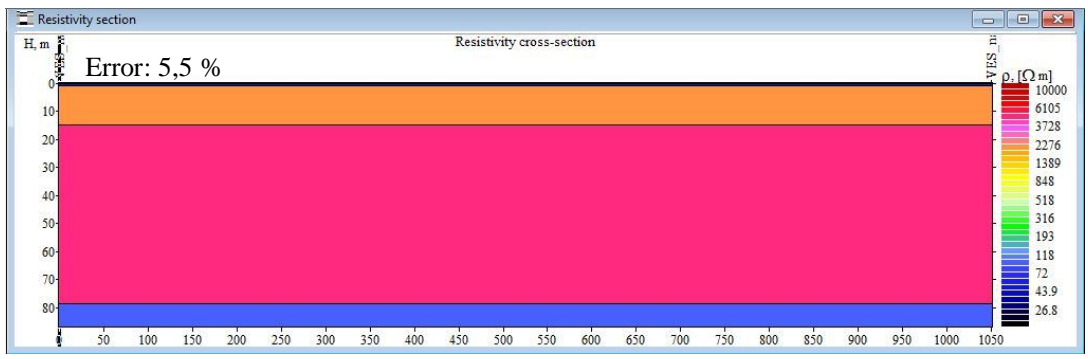

Gambar 4 Penampang Resistivity Section L2

Tabel 2 memperlihatkan perkiraan lapisan batuan untuk L2. Gambar 4 menunjukkan hasil penampang 1 dimensi berdasarkan Tabel 2. Lokasi ini memiliki 4 jenis lapisan batuan dengan nilai resistivitas berbeda. Lapisan I diinterpretasikan sebagai lapisan tanah penutup dengan nilai resistivitas $48,8 \Omega \mathrm{m}$. Lapisan II mempunyai nilai resistivitas $1931 \Omega \mathrm{m}$ diinterpretasikan sebagai lapisan batuan vulkanik. Sama halnya dengan lapisan III dengan nilai resistivitas $4596 \Omega \mathrm{m}$ juga diinterpretasikan sebagai lapisan batuan vulkanik. Berdasarkan stratigrafi daerah Gunung Talang, daerah Bukit Gadang ini didominasi oleh lava andesitik dan aliran piroklastik. Berdasarkan nilai resistivitasnya, lapisan II termasuk jenis batuan andesit dan lapisan III termasuk jenis batuan tuff. Pada lapisan IV terjadinya penurunan nilai resistivitas 
batuan yaitu $86,1 \Omega \mathrm{m}$. Hal ini menandakan terjadinya pelapukan batuan menuju batuan sedimen berupa batuan lempung. Lapisan ini diindikasikan bukan merupakan lapisan caprock panas bumi karena nilai resistivitasnya $>20 \Omega \mathrm{m}$. Melihat posisinya yang dangkal tetapi dekat dengan daerah manifestasi, maka lapisan ini diduga sebagai reservoir air tanah yang terpengaruh oleh aliran out flow fluida panas bumi yang keluar pada daerah manifestasi. Lapisan ini dapat juga berfungsi sebagai daerah aliran recharge area panas bumi Gunung Talang.

Pada L2, kedalaman yang bisa diidentifikasi hanya sampai 78,7 m, sedangkan daerah lainnya penetrasinya lebih dalam $>100 \mathrm{~m}$. Hal ini terjadi karena lintasan ini berada di dekat pemukiman warga dan juga di dekat daerah persawahan. Akibatnya ketika melakukan pengukuran, aliran arus listrik mengalami gangguan, sehingga penetrasinya tidak terlalu dalam. Daerah ini memungkinkan adanya keberadaan caprock, karena terdapatnya manifestasi permukaan berupa mata air panas Bukit Gadang. Selain itu, daerah ini juga dekat dengan daerah Batu Berjanjang yang sudah teridentifikasi keberadaan caprocknya. Oleh karena itu, perlu dilakukan penelitian lebih lanjut dengan menggunakan metode yang penetrasinya lebih dalam

Tabel 3 Hasil Pengolahan dan interpretasi data L3

\begin{tabular}{ccccc}
\hline Lapisan & $\begin{array}{c}\text { Resistivitas } \\
(\mathbf{\Omega} \mathbf{m})\end{array}$ & $\begin{array}{c}\text { Ketebalan } \\
(\mathbf{m})\end{array}$ & $\begin{array}{c}\text { Kedalaman } \\
(\mathbf{m})\end{array}$ & Jenis Lapisan Batuan \\
\hline I & 39,6 & 0,9 & $0,0-0,9$ & Lapisan tanah penutup \\
II & 2380 & 26,8 & $0,9-27,7$ & Lapisan batuan vulkanik \\
III & 4735 & 116 & $27,7-144$ & Lapisan batuan vulkanik \\
IV & 109 & - & $144-$ & Lapisan batuan Alluvium \\
\hline
\end{tabular}

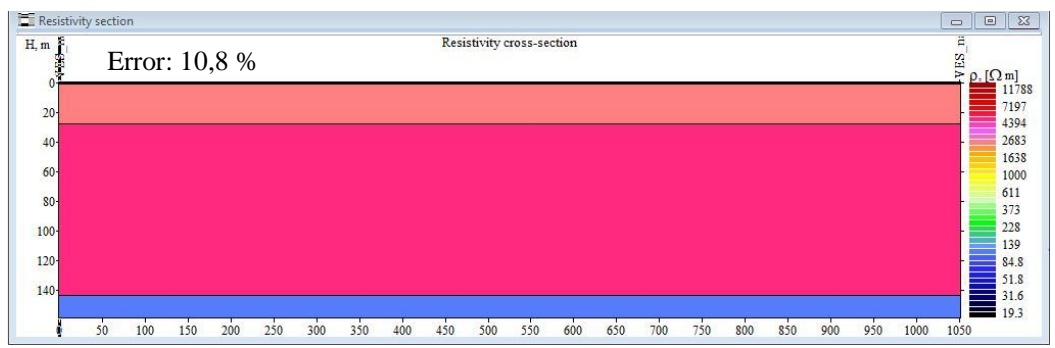

Gambar 5 Penampang Resistivity Section L3

Tabel 3 menunjukkan hasil pengolahan dan interpretasi data L3 yang berada di daerah Bukit Sundi. Gambar 5 menunjukkan hasil penampang 1 dimensi berdasarkan Tabel 3. Berdasarkan stratigrafinya, daerah ini berada pada satuan batuan endapan permukaan. Penyusun batuan ini terdiri dari material - material vulkanik tua yang didominasi oleh lava andesitik. Tabel tersebut menunjukkan adanya 4 jenis lapisan batuan. Lapisan I dengan nilai resistivitas $39,6 \Omega \mathrm{m}$ diinterpretasikan sebagai lapisan penutup (top soil) dengan ketebalan lapisan 0,9 $\mathrm{m}$. Lapisan II dengan nilai resistivitas $2380 \Omega$ m diinterpretasikan sebagai lapisan batuan vulkanik berupa batuan andesit. Lapisan III dengan nilai resistivitas $4735 \Omega \mathrm{m}$ juga diinterpretasikan sebagai batuan vulkanik berupa batuan tuff. Lapisan IV dengan nilai resistivitas $109 \Omega \mathrm{m}$ diinterpretasikan sebagi batuan Alluvium karena terjadinya penurunan nilai resistivitas dari lapisan III ke IV akibat adanya pelapukan batuan. Lapisan ini terdiri dari material seukuran bongkah, kerikil dan pasir (Noor, 2012). Pada lapisan ini tidak mengindikasikan adanya caprock panas bumi karena nilai resistivitasnya $>20 \Omega \mathrm{m}$.

Berbeda dengan 2 daerah sebelumnya, pada L3 tidak ada manifestasi panas bumi berupa mata air panas atau lainnya. Tujuan dilakukannya penelitian di daerah ini adalah agar didapatkan caprock yang baik dengan tidak adanya rekahan yang memunculkan manifestasi ke permukaan. Namun, berdasarkan nilai resistivitas yang $>20 \Omega \mathrm{m}$ dan kedalaman $144 \mathrm{~m}$, pada L3 tida ada indikasi keberadaan caprock. Lapisan konduktif ini diduga bukan berasal dari pemanasan batuan dasar (berupa magma) di bawah titik sumber, tetapi melalui aliran panas dari daerah lain yang muncul akibat adanya rekahan pada batuan.

Berdasarkan identifikasi 3 lintasan diatas terdapat perbedaan jumlah lapisan batuan dengan data L1 yang memiliki 3 lapisan batuan. Pada L2 dan L3 ditemukan adanya 4 jenis lapisan batuan ditandai dengan perbedaan nilai resistivitas batuannya. Hal ini dikarenakan 
adanya perbedaan stratigrafi daerah penelitian. Daerah pada L1 didominasi oleh batuan piroklastik, sedangkan daerah pada L2 dan L3 didominasi oleh lava andesitik.

\section{KESIMPULAN}

Berdasarkan hasil penampang ID menggunakan software IPI2WIN diperoleh kedalaman lapisan batuan maksimum $144 \mathrm{~m}$ yang terdapat pada L3. Penggunaan metode resistivitas Konfigurasi Wenner pada penelitian ini hanya mendapatkan 1 lintasan pengukuran yang mengindikasikan adanya keberadaan caprock panas bumi yaitu L1 (Cupak) dengan nilai resistivitas kecil dari $20 \Omega \mathrm{m}$ pada kedalaman $109 \mathrm{~m}$.

\section{DAFTAR PUSTAKA}

Arif, Sandra, dan Musa, T. D., Identifikasi Sebaran Panas bumi Menggunakan Metode Geolistrik Hambatan Jenis di Desa Wani Tiga, Kabupaten Donggala. Journal of Natural Science, 4, 338-347, 2015.

Arnata, D. P. B., Musa, M. D. T., dan Sabhan, Identifikasi Sistem Panas Bumi di Desa Masaingi Dengan Menggunakan Metode Geolistrik, Journal of Natural Science, 1, 1-6, 2012.

Dickson, M.H. dan Fanelli, M., Geothermal Energy: Utilization and Technology, John Wiley \& Sons, India, 2003

Kholid, M., dan Marpaung, H., Survei Megnetotellurik daerah Panas Bumi Bukit Kili Gunung Talang Kabupaten Solok. Sumatera Barat. Prosiding Hasil Kegiatan Pusat Sumber Daya Geologi, 2011.

Haerudin, N., Pardede, V. J., dan Rasimeng, S., Analisis Reservoar Daerah Potensi Panasbumi Gunung Rajabasa Kalianda dengan Metode Tahanan Jenis dan Geotermometer, Jurnal Ilmu Dasar, 10, 141-146, 2009.

Hendrajaya, L., dan Arif, I., Geolistrik Tahanan Jenis, Laboratorium Fisika Bumi, Jurusan FMIPA ITB, Bandung, 1988.

Maruly, R., Analisis Data Resistivitas Untuk Identifikasi Fluida Di Daerah Prospek Panas bumi Way Ratai Kabupaten Pesawaran, Skripsi, Universitas Lampung, 2016.

Milsom, J., Field Geophysics, Third Edition, John Wiley \& Sons, Chichester, Inggris, 2003

Minarto, E., Pemodelan Inversi Data Geolistrik untuk Menentukan Struktur Perlapisan Bawah Permukaan Daerah Panas Bumi Mataloko, Jurnal Fisika dan Aplikasinya, 3, 1-5, 2007.

Munandar, A., Suhanto, E., Kusnadi, D., Idral, A., dan Solaviah, M., Penyelidikan Terpadu Daerah Panas Bumi Gunung Talang Kabupaten Solok-Sumatera Barat. Kolokium Hasil Kegiatan Inventarisasi Sumber Daya Mineral, Departemen Sumber Daya Mineral, Jakarta, 2003.

Noor, D., Pengantar Geologi, Edisi Kedua, Program Studi Teknik Geologi, Universitas Pakuan, Bogor, 2012.

Reynolds, J. M., An Introduction to Applied and Environmental Geophysic, John Wiley dan Sons, Chichester, Inggris, 1997.

Simsek, S., dan Demir, A., Reservoir And Caprock Characteristics of Some Geothermal Fields In Turkey And Encountered Problems Based On Lithology, Journal of the Geothermal Research Society of Japan, 13, 191-204, 1991.

Telford, W.M., Geldart, L.P., Sheriff, R.E., and Keys, D.A., Applied Geophysics, Cambridge University, USA, 1990. 